\title{
Analysis of Problems and Key Process Parameters in Household Biomass Gasification System
}

\author{
Zhenbo Bao ${ }^{1, a^{*}}$, Longxiang Yang ${ }^{1, b}$, Jinxing Peng ${ }^{1, c}$ and Fan Yang ${ }^{1, d}$ \\ ${ }^{1}$ Engineering and Technology College, Tianjin Agricultural University, Tianjin, China, 300384 \\ a*zhenbobao@sohu.com, bylx619474511@163.com, 'pengjinxing@163.com, \\ dfanyang20062008@126.com
}

Keywords: Biomass; Household gasification system; Tar; Gasification gas; Technical parameters

\begin{abstract}
Biomass being clean and renewable energy with low pollution, the utilization of it can reduce greenhouse gas emissions, solve ecological problems and achieve sustainable development. Biomass gasification is one of the main forms of straw biomass energy utilization, and household biomass gasification system is one form of gasification utilization. Household biomass gasification system with the problems of heating value of gasification gas is low, tar and ash in gasification gas is more and material supply inconvenience, which restricted its application. By reviewing the literature and practical experience, the problems of household biomass gasification system, such as the high impurity content of tar and dust in the gasification gas, poor adaptability of gasifier to raw materials, low calorific value of gasification gas and instability of gasification gas production were summarized; and the key parameters of household gasification system, such as the solid particle size of biomass material, the humidity and compaction degree of biomass material, the height of biological material layer, the flow rate of gasifier agent and the temperature of gasification reaction were analyzed. It will help to optimize the structure of household gasification biomass system and optimize the process parameters, improve the utilization efficiency of household biomass gasification system.
\end{abstract}

\section{Introduction}

The energy is related to the survival and development of human society, the development and utilization of recyclable renewable clean energy, reducing dependence on petrochemical energy and consumption, has become the world's consensus to ease the energy crisis [1-3]. Being a clean and renewable energy with low pollution, the development and utilization of biomass can reduce greenhouse gas emissions, solve ecological problems and achieve sustainable development, which has increasingly attracted attention of countries around the world [4-6]. Straw biomass is an important component of biomass, the annual output of China's straw biomass is about 700 million, part of used as livestock feed, fertilizer, paper making raw materials, etc., about 400 million tons of straw can be used as biomass energy use. Straw is discarded or burned in the field, resulting in waste of resources and environmental pollution, but also causing harm on aviation and road traffic safety. Untreated straw direct combustion efficiency is low, can cause indirectly waste of resources and some pollution to the environment [6-9]. Biomass gasification is one of the main forms of straw biomass energy utilization; its application includes two major forms: large-scale pipeline biomass gasification station and small-scale household biomass gasification system [2-7]. In the use of large-scale pipeline biomass gasification station, there are the following problems: the gasification system is huge, resulting in high invest cost and maintenance cost; gasification equipment utilization rate is low resulting in high gasification gas cost; tar the content of tar in gasification gas is high affecting its promotion and application. The problems of large-scale pipeline biomass gasification station indirectly promote the development and utilization of household biomass gasification system [4-8]. Household biomass gasification system has the advantages of simple structure, short pipeline, which weaken the influence of tar, a key factor which restricts the application and popularization of centralized gas supply; operation and maintenance is convenient, low maintenance and operating costs; meeting the real demand of farmers lower economic costs, etc., suitable for the promotion use of rural areas living scattered and economy is relatively backward. But, household biomass 
gasification system has the following problems: the heating value of biomass gasification gas is low, the instability of gas, tar and ash in gasification gas is more, and material supply inconvenience, which severely restricted the application and popularization of household biomass gasification system [7-10].

\section{The Problems in the Use of Household Biomass Gasification System}

Household biomass gasification combustion system has the following problems, restricting its use and promotion, the specific problems and their hazards described in Table 1[3-10].

Table 1 The problems of household biomass gasification system

\begin{tabular}{|c|c|}
\hline Problems & Specific elaboration \\
\hline $\begin{array}{l}\text { Tar and ash } \\
\text { in } \\
\text { gasification } \\
\text { gas too } \\
\text { much }\end{array}$ & $\begin{array}{l}\text { The tar, dust and other impurities in gasification gas, not only cause damage to } \\
\text { gasification equipment, but also cause environmental pollution. With the } \\
\text { temperature decreases, the tar can condense in the wall and stomata of gas pipeline, } \\
\text { can easily lead to obstruction of gas pipeline, valve and stove rotating parts stuck. } \\
\text { When the tar into the stove with low-temperature combustion, easy to produce } \\
\text { irritation and unpleasant taste. }\end{array}$ \\
\hline $\begin{array}{l}\text { Biomass } \\
\text { feedstock } \\
\text { has poor } \\
\text { process } \\
\text { adaptability }\end{array}$ & $\begin{array}{l}\text { Different types of raw materials have different gasification characteristics; the } \\
\text { poor adaptability of biomass raw materials mainly refers to two aspects: on the one } \\
\text { hand, the adaptability of different types of raw materials is poor; on the other hand } \\
\text { the adaptability of same raw materials of different size specifications is poor. The } \\
\text { particle size of raw materials has a certain standard, if not within the standard } \\
\text { range, the gasification is affected. The materials are crushed and compressed to } \\
\text { obtain the material with the size and shape specifications, which is beneficial to the } \\
\text { stable operation of the gasification process. }\end{array}$ \\
\hline $\begin{array}{l}\text { The } \\
\text { calorific } \\
\text { value of } \\
\text { gasification } \\
\text { gas is low }\end{array}$ & $\begin{array}{l}\text { Gasification gas of low calorific value will lead to low flame temperature, wind } \\
\text { resistance is weak and prone to off fire; it need larger gas tank size to store lots of } \\
\text { gasification gas, which lead to increase investment and poor economy; the tar in } \\
\text { the gasification gas incomplete combustion easy to produce stimulation, } \\
\text { unpleasant taste, affecting the user's health. Household gasification system using } \\
\text { air as gasification agent, the introduction of a large number of inert } \mathrm{N}_{2} \text { diluted } \\
\text { gasification gas, is the main reason causing gas calorific low value. Adopting } \\
\text { steam gasification agent to a certain extent can improve gasification heat value. }\end{array}$ \\
\hline $\begin{array}{l}\text { Production } \\
\text { of gas is not } \\
\text { stable }\end{array}$ & $\begin{array}{l}\text { The instability of gas production is mainly caused by the deterioration of the } \\
\text { gasification reaction in the gasification furnace, maintaining the position and } \\
\text { temperature of each reaction zone in the furnace is the key factor to ensure the } \\
\text { stability of the gasification reaction. Factors affecting the relative stability of the } \\
\text { gasification reaction zone are as follows: bridging, coking, uneven distribution of } \\
\text { air and uneven ignition; low bulk density of biomass raw material and poor } \\
\text { mobility caused by its long fibrous structure are the main reasons for bridging } \\
\text { phenomena. When the material is gasified, if the air supply in the furnace is not } \\
\text { uniform, the air supply is insufficient and the ignition is not uniform, easy to } \\
\text { leading the phenomenon of local burn-through and burn impervious, and the holes } \\
\text { will be formed and expanded until the perforation; as the ash melting point of the } \\
\text { biomass is low, but also easy to lead to over-temperature furnace coking. The } \\
\text { temperature changes in addition to the above factors, but also with the gasifier } \\
\text { structure, material humidity and other factors. }\end{array}$ \\
\hline
\end{tabular}

The above problems affect the normal operation of household gasification system, and the quality of gasification combustible gas is not high, restricting the promotion of household gasification system. 


\section{The Key Technical Parameters of Household Biomass Gasification System}

From the research and development trend of small-scale household biomass gasification system, optimizing the structure of the gasifier and the process parameters of the gasification technology can effectively solve the problems existing in the household biomass gasification system, maintain stable operation of the gasification process, improve the thermal conversion efficiency, reduce and effectively utilize the tar in the gasification process to obtain clean, high calorific value gasification gas. Some technological process and technical parameters of household biomass gasification system, such as: the biomass raw material is crushed and compressed into regular particles, the height of the biomass raw material in the gasification furnace, the flow rate of the air and steam vaporizing agent, humidity and compaction degree of biomass materials, and so on, have a direct and important impact on the process of gasification combustion. The key technical parameters of household biomass gasification system are shown in table 2 [3-10].

Table 2 The key technical parameters of household biomass gasification system

\begin{tabular}{|c|c|}
\hline Parameters & Specific elaboration \\
\hline $\begin{array}{lr}\text { Size } & \text { of } \\
\text { biomass } & \text { raw } \\
\text { material } & \\
\text { particles } & \end{array}$ & $\begin{array}{l}\text { Biomass raw materials are crushed and compressed into solid particles of regular } \\
\text { size for gasification combustion, which is beneficial to optimization of gasification } \\
\text { process parameters and ensure the stable operation of gasification process. The } \\
\text { volume shape of the biomass fuel particles is closely related to the bypassing and } \\
\text { burning-through of the biomass fuel combustion gasification process, which have } \\
\text { great influence on the biomass gasification. Under normal circumstances, with the } \\
\text { biomass feedstock particle size decreases, the proportion of } \mathrm{CH}_{4}, \mathrm{CO} \text { inside the } \\
\text { gasification gas increased and the proportion of } \mathrm{CO}_{2} \text { decreased. }\end{array}$ \\
\hline $\begin{array}{l}\text { Height of the } \\
\text { biomass raw } \\
\text { material layer }\end{array}$ & $\begin{array}{l}\text { The gasification reaction temperature and the composition of the combustible gas } \\
\text { in the gasification gas are affected by the height of the biomass raw material layer. } \\
\text { the up-sucking gasifier, for example, the raw material layer structure from bottom } \\
\text { to top are oxide layer, reduction layer, pyrolysis layer and dry layer, for example, In } \\
\text { order to form such a material structure, the material layer must reach a certain } \\
\text { height. The drying layer plays an important role in reducing the temperature of the } \\
\text { outlet gas, recovering heat, and filtering impurities such as tar and dust in the } \\
\text { "coarse gas" and reducing the burden on the purification system. }\end{array}$ \\
\hline $\begin{array}{l}\text { Moisture } \\
\text { content and } \\
\text { compaction } \\
\text { degree of } \\
\text { biomass raw } \\
\text { material layer }\end{array}$ & $\begin{array}{l}\text { The moisture content and compaction degree of the biomass fuel particles are } \\
\text { closely related to the bypassing and burning-through of the biomass fuel } \\
\text { combustion gasification process, which have great influence on the biomass } \\
\text { gasification. In addition, the humidity of the biomass feedstock has a significant } \\
\text { impact on the calorific value of the biomass gasification gas, the efficiency of the } \\
\text { gasifier, and the retention and collection of the tar in the biomass feedstock. The } \\
\text { compaction degree of biomass material has important influence on the stable } \\
\text { operation of gasification process and the quality of gasification gas, such as } \\
\text { biomass material flows in the cavity during the gasification process and prevents } \\
\text { gasification combustion, "Burn through", "coke" and other conditions. }\end{array}$ \\
\hline $\begin{array}{l}\text { Flow rate of air } \\
\text { and water } \\
\text { gasification } \\
\text { agent }\end{array}$ & $\begin{array}{l}\text { Gasification agent is the main factor affecting the biomass gasification. Air is the } \\
\text { most commonly used gasification agent. The flow rate and distribution structure of } \\
\text { gasification agent affect the gas composition, gasification efficiency and } \\
\text { combustion calorific value. }\end{array}$ \\
\hline $\begin{array}{l}\text { Reaction } \\
\text { temperature }\end{array}$ & $\begin{array}{l}\text { The reaction temperature is one of the most important gasification process } \\
\text { parameters, and the reaction temperature not only affects the accumulation and } \\
\text { sintering of fly ash. And the temperature increases the gasification gas in the } \mathrm{CO} \\
\text { and } \mathrm{H}_{2} \text { content, reducing the } \mathrm{CO}_{2}, \mathrm{CH}_{4} \text { and } \mathrm{H}_{2} \mathrm{O} \text { content. }\end{array}$ \\
\hline
\end{tabular}


In addition to the technical parameters listed in Table 2, the parameters such as the structure of the gasifier, the type of the biomass feedstock, and the gasification reaction time have a direct and important influence on the gasification reaction and the gasification gas quality.

\section{Summary}

Household biomass gasification system has the advantages of simple structure, short gasification pipeline, convenient operation and low cost. However, due to the existence of high content of impurities such as tar and dust, it restricts the use and popularization. By analyzing and summarizing the problems of high impurity content of tar and dust in the gasification system of household, poor adaptability of gasifier to raw materials, low calorific value of gasification gas and instability of gasification gas production, the key parameters of household gasification system, such as the solid particle size of biomass material, the humidity and compaction degree of biomass material, the height of biological material layer, the flow rate of gasifier agent and the temperature of gasification reaction were analyzed. It will help to optimize the structure of household gasification biomass system and optimize the process parameters, improve the utilization efficiency of household biomass gasification system, improve the efficiency of biomass energy use in rural areas, and alleviate the energy crisis and environmental pollution.

\section{Acknowledgements}

The research work was supported by Tianjin College Students' Innovative Entrepreneurial Training Program No. 201610061022 and No. 201610061024.

\section{References}

[1] G. L. Zhang, Z. T. Zhang, Z. B. Zhao: Journal of Agricultural Mechanization Research, (2011) No.8, p.8.

[2] C. Z. Wu, H. C. Liu, X. L. Xiu: Journal of Fuel Chemistry and Technology, Vol. 41 (2013) No.7, p.798-804.

[3] X. Zhang, Z. S. Cai, Y. Chen: Journal of Agricultural Mechanization Research, (2015) No.2, p.1-5.

[4] Y. L. Bao, Z. B. Bao, D. C. Jin: Mechanical Engineer, (2018) No.8, p.149-151.

[5] D Fouquet, T Johansson: Energy Policy, Vol. 36 (2013) No.11, p.4079-4092.

[6] W. J. Li, P. Gao: Environment and Development, Vol. 25 (2013) No.12, p.4-7.

[7] Arena U: Waste Management, (2012) No.32, p.625-39.

[8] Y. M. Zhang, Z. W. Yu, G. Wang: Journal of Agricultural Mechanization Research, (2013) No.10, p.210-213.

[9] X. Zhang, Z. S. Cai, L. H. Chen: Renewable Energy Resources, Vol. 32(2014) No.12, p.1917-1921.

[10] H. Guo, T. Zhu, J. P. Wang: Guangzhou Chemical Industry, Vol. 42(2014) No.18, p.35-37. 